\title{
Growth of microorganisms in rhizosphere of plants of hulless oats and productivity of the crop under action of fertilizers and biological preparation Microhumini
}

V. Volkogon,

Doctor of Agricultural Sciences, Corresponding Member of NAAS

A. Berdnikov,

Doctor of Agricultural Sciences, Corresponding Member of NAAS

L. Tokmakova,

Candidate of Agricultural Sciences

I. Larchenko

Institute of Agricultural Microbiology and Agricultural Production NAAS

The purpose. To study features of growth of micro- organisms in rhizosphere soil of plants of hulless oats and productivity of the crop under action of fertilizers and microbial specimen. Methods. Field researches, conventional microbiological, gas-and-chromatographic determination of potential activity of nitrogen fixation and potential emission of N20. Results. After-effect of muck and green fertilizers, as well as doses of mineral fertilizers, which did not exceed N80P:t0K45, promoted growth of agronomically valuable microorganisms at cultivation of hulless oats on sod-podzolic soil and formation of productivity of the crop. Application of microbial specimen Microhumin was effective. Its influence on productivity of oats in experiment was equivalent to action of mineral fertilizers in dose of $\mathrm{N} P \mathrm{P} \mathrm{K}_{\|}$. Conclusions. Features of formation of communities of microorganisms in rhizosphere soil of plants and manifestation of their functional activity was the reliable indicator of ecological state of soils of agrocnosises.

Key words: nitrogen fixation, denitrifying process, microorganisms, hulless oat, green manure crops, fertilizers.

Background. Soil bacteria and microscopic fungi are the essential and integral part of soilmicroorganisms-plant system. Plants, provided with a full set of microorganisms exist in a comfortable trophic state, gaining protection against pathogenic organisms and, as the result, realizing its productivity potential [13]. Consequently, modern farming practices should take into account the response or adaptive capacities of soil microorganisms to anthropogenic pressure. Microbial preparations can be an important factor in optimizing microorganisms associations in agrocenoses, as their main function is to regulate the number and activity of microbiota through the sharp increase in the number of selected beneficial forms of microorganisms and optimization of their interaction with plants [4-6].

The studiesof biological preparations and their action on the formation of microbial associations in the root zone of cultured plants at their cultivation in different agricultural backgrounds are of the big interest especially in view of selection of their optimal combinations.

Purpose. The purpose of given research was to determine the impact of biogenic and abiogenicfactors in the naked oats growing technology on the formation of microorganisms associations and crop productivity.

Methods. The study was performed during 2011 - 2015years on the research fields of the Institute of Agricultural Microbiology and Agricultural Production in the established experimental plots on sod-podzolic soils(short crop rotation: potato - naked oats - lupine - winter rye) upon the different fertilizing systems. All variants were duplicated in blocks with and without application of microbial preparation. 
Both blocks had variants with fertilizers used in doses $N_{\sharp} P_{\sharp} K_{\sharp}, N_{\sharp} P_{\sharp} K_{k}$ and $N_{\sharp} P_{i} K_{i}$. Besides mineral fertilizers the first year aftereffect of $40 \mathrm{t} / \mathrm{ha}$ of manure, organic-mineral fertilizer ( $40 \mathrm{t} / \mathrm{ha}$ manure with the addition of $\mathrm{N}_{\mathrm{i}} \mathrm{P}_{\mathrm{i}} \mathrm{K}_{i}$ ), and green manure (oil radish) were investigated. Organic fertilizers were also used under cultivation of pre-crop potatoes.

Pre-sowing inoculation of seeds of naked oats (Smachniy variety) was performed with the microbial preparation Microhumin(TU U 24.1-00497360-007).

The total number of microorganisms and representatives of different ecological and trophic groups was determined using conventional microbiological methods[7]. The potential activity of nitrogen fixation in the rhizosphere soilswas studied using M. Umarovmethod [8]. The potential denitrification activity was determined using the acetylene method [9]. Yield reporting and statistical data processing was performed using standard statistical methods [10].

Results.Biogenicand abiotic fertilization factors significantly affect the formation of microbial associations in the root zone of naked oats plants. Thus, the increase in number of ammonifierbacteria compared to control indices in all variants with fertilizers was observed. The most significant increase was noticed in the variants with medium and high doses of mineral fertilizers. The positive aftereffect on the development of ammonifierbacteria in plants rhizosphere was noticed in the variants with the manure and green manure application and use of microbial preparation Microhumin. The reduction of given effect was observed by the end of the growing season.

At the same time, the recorded numbers of bacteria that metabolize mainly mineral nitrogenwas different comparing to the growth characteristics of ammonifiermicroorganisms. Thus, under the use of biological preparation for pre-sowing seedsinoculation the reduction of the number of ammonifierbacteria was observed. This can be explained by the active influence of the microbial preparation on plants development that requires large quantities of mineral nitrogen for the constructive crop metabolism and, correspondingly, reduces the amount of substrate (mineral nitrogen) in the root zone of plants required for the growth and development of these bacteria, thus affecting their number.

Aftereffectof manure had a positive effect on the development nitrogen fixating bacteria and, therefore,on the process of nitrogen fixation in the rhizosphere of oats plants (Table 1). The low fertilizer rateshad stimulatedthis activity from the tilleringstage, medium rates - starting from the stem elongation, while in variants with high fertilizer rates $\left(\mathrm{N}_{\mathrm{i}} \mathrm{P}_{\mathrm{i}} \mathrm{K}_{\mathrm{i}}\right)$ the restoration of nitrogenaseactivity was observed only at the end of the growing season. The aftereffect of green manure, especially in variants with Microhuminom had a clear positive influence on the nitrogen fixation process.

The study of population of denitrifying microorganisms indicates the growth of their numbers in almost all variants during the first two study checks, except for variant with the aftereffectof green manure. During the milky ripeness the number of denitrifying bacteria had decreased in all variants, especially under the use of biological preparation. The study of potential emission of $\mathrm{N} O \mathrm{O}$ in dynamics had revealed the similar dependencesas described above for the ammonifiermicroorganisms (Table2). 
Table 1.The effect of seeds bacterization and fertilizers on the potential nitrogen fixation activity of rhizosphere soil of naked oats plants, $n m o l C_{l} H_{4} / g$ soil per hour

\begin{tabular}{|c|c|c|c|}
\hline Variants & $\begin{array}{l}\text { Tillering } \\
\text { stage }\end{array}$ & $\begin{array}{l}\text { Stem } \\
\text { elongation }\end{array}$ & $\begin{array}{l}\text { Milky-wax } \\
\text { ripeness }\end{array}$ \\
\hline \multicolumn{4}{|l|}{ Without inoculation } \\
\hline Without fertilizers (control) & $3.4 \pm 0.3$ & $0.8 \pm 0.1$ & $1.5 \pm 0.2$ \\
\hline Aftereffect of manure $40 \mathrm{t} / \mathrm{ha}$ & $4.1 \pm 0.5$ & $1.8 \pm 0.1$ & $1.9 \pm 1.7$ \\
\hline $\mathrm{N}_{\sharp} \mathrm{P}_{\|} \mathrm{K}_{\|}$ & $5.9 \pm 0.3$ & $2.5 \pm 0.3$ & $2.1 \pm 0.3$ \\
\hline $\mathrm{N}_{\mathbb{N}} \mathrm{P}_{\mathfrak{y}} \mathrm{K}_{\mathrm{f}}$ & $3.1 \pm 0.4$ & $2.7 \pm 0.2$ & $3.1 \pm 0.1$ \\
\hline $\mathrm{N}_{\mathbb{P}} \mathrm{P}_{\mathfrak{H}} \mathrm{K}_{\tilde{z}}$ & $2.2 \pm 0.2$ & $1.0 \pm 0.2$ & $2.3 \pm 0.4$ \\
\hline Aftereffect of manure $40 \mathrm{t} / \mathrm{ha}+\mathrm{N}_{\mathrm{A}} \mathrm{P}_{\mathrm{B}} \mathrm{K}_{\mathrm{f}}$ & $3.5 \pm 0.8$ & $1.0 \pm 0.2$ & $2.0 \pm 0.1$ \\
\hline Aftereffect of green manure & $4.0 \pm 0.2$ & $1.8 \pm 0.2$ & $2.4 \pm 0.2$ \\
\hline \multicolumn{4}{|l|}{ Inoculation with Microhumin } \\
\hline Without fertilizers (control) & $4.6 \pm 0.8$ & $1.0 \pm 0.2$ & $2.6 \pm 0.3$ \\
\hline Aftereffect of manure $40 \mathrm{t} / \mathrm{ha}$ & $6.2 \pm 0.3$ & $2.2 \pm 0.3$ & $6.4 \pm 0.5$ \\
\hline $\mathrm{N}_{\sharp} \mathrm{P}_{\sharp} \mathrm{K}_{\Perp}$ & $9.8 \pm 1.1$ & $2.9 \pm 0.3$ & $4.1 \pm 0.4$ \\
\hline $\mathrm{N}_{\mathbb{N} \mathrm{P}} \mathrm{K}_{\mathrm{k}}$ & $5.5 \pm 0.8$ & $3.5 \pm 0.2$ & $4.3 \pm 0.4$ \\
\hline $\mathrm{N}_{\mathrm{P}} \mathrm{P}_{\mathrm{i}} \mathrm{K}_{\mathrm{i}}$ & $3.8 \pm 0.8$ & $1.4 \pm 0.1$ & $2.5 \pm 0.2$ \\
\hline Aftereffect of manure $40 \mathrm{t} / \mathrm{ha}+\mathrm{N}_{\mathrm{i}} \mathrm{P}_{\mathrm{A}} \mathrm{K}_{\mathrm{k}}$ & $3.6 \pm 0.2$ & $1.5 \pm 0.1$ & $3.0 \pm 0.2$ \\
\hline Aftereffect of green manure & $5.0 \pm 0.2$ & $2.4 \pm 0.3$ & $2.9 \pm 0.5$ \\
\hline
\end{tabular}

Table 2. The effect of seeds bacterization and fertilizers on the potential denitrification activity of rhizosphere soil of naked oats plants, $n$ molN $\mathrm{O} / \mathrm{g}$ soil per hour

\begin{tabular}{|c|c|c|c|}
\hline Variants & $\begin{array}{l}\text { Tillering } \\
\text { stage }\end{array}$ & $\begin{array}{l}\text { Stem } \\
\text { elongation }\end{array}$ & $\begin{array}{l}\text { Milky-wax } \\
\text { ripeness }\end{array}$ \\
\hline \multicolumn{4}{|l|}{ Without inoculation } \\
\hline Without fertilizers (control) & $6.4 \pm 0.8$ & $4.6 \pm 1.0$ & $3.0 \pm 1.1$ \\
\hline Aftereffect of manure $40 \mathrm{t} / \mathrm{ha}$ & $13.6 \pm 2.0$ & $10.6 \pm 2.8$ & $9.1 \pm 0.4$ \\
\hline $\mathrm{N}_{\sharp} \mathrm{P}_{\|} \mathrm{K}_{\|}$ & $10.7 \pm 2.7$ & $9.1 \pm 1.5$ & $7.9 \pm 0.5$ \\
\hline $\mathrm{N}_{\mathbb{B}} \mathrm{P}_{\mathfrak{x}} \mathrm{K}_{\mathrm{f}}$ & $14.1 \pm 2.7$ & $14.4 \pm 1.2$ & $11.3 \pm 0.7$ \\
\hline $\mathrm{N}_{\mathfrak{y}} \mathrm{P}_{\mathfrak{y}} \mathrm{K}_{\tilde{B}}$ & $17.5 \pm 1.4$ & $20.1 \pm 2.1$ & $14.4 \pm 1.4$ \\
\hline Aftereffect of manure $40 \mathrm{t} / \mathrm{ha}+\mathrm{N}_{\mathrm{i}} \mathrm{P}_{\mathrm{S}} \mathrm{K}_{\mathrm{s}}$ & $15.7 \pm 2.5$ & $12.5 \pm 0.9$ & $10.6 \pm 0.3$ \\
\hline Aftereffect of green manure & $7.3 \pm 0.2$ & $6.2 \pm 1.1$ & $3.6 \pm 0.5$ \\
\hline \multicolumn{4}{|l|}{ Inoculation with Microhumin } \\
\hline Without fertilizers (control) & $6.5 \pm 0.8$ & $4.4 \pm 0.7$ & $2.4 \pm 0.5$ \\
\hline Aftereffect of manure $40 \mathrm{t} / \mathrm{ha}$ & $18.6 \pm 2.5$ & $9.4 \pm 1.4$ & $8.8 \pm 1.0$ \\
\hline $\mathrm{N}_{\sharp} \mathrm{P}_{\sharp} \mathrm{K}_{\|}$ & $11.0 \pm 0.5$ & $7.4 \pm 1.1$ & $7.1 \pm 0.5$ \\
\hline $\mathrm{N}_{\sharp} \mathrm{P}_{\sharp} \mathrm{K}_{k}$ & $14.6 \pm 2.3$ & $10.4 \pm 0.8$ & $8.9 \pm 0.3$ \\
\hline $\mathrm{N}_{\sharp} P_{\mathfrak{A}} \mathrm{K}_{\tilde{3}}$ & $17.9 \pm 2.1$ & $14.7 \pm 1.0$ & $14.4 \pm 1.0$ \\
\hline Aftereffect of manure $40 \mathrm{t} / \mathrm{ha}+\mathrm{N}_{\mathrm{i}} \mathrm{P}_{\mathrm{i}} \mathrm{K}_{\mathrm{s}}$ & $16.6 \pm 1.4$ & $11.9 \pm 0.9$ & $11.5 \pm 0.7$ \\
\hline Aftereffect of green manure & $7.6 \pm 0.7$ & $5.4 \pm 0.5$ & $3.3 \pm 0.7$ \\
\hline
\end{tabular}

The positive action of Microhumin was observed on all fertilizer backgrounds. The reduction of gaseous nitrogen losses of was observed starting from the stem elongation stages in the block of seeds bacterization(variants with low and medium experimentalrates of mineral fertilizers, as well as aftereffect of 
green manure application). By the end of the growing season the decrease of biological denitrification activity in rhizosphere of inoculated oats plantswas also observed in the variant with manure aftereffect.

The least activity of biological denitrification was observed in in variants with green manure after effect.

The action of fertilizers on the development of the microbiota can be described using the dynamics of phosphorous mobilizing bacteria as an example (Fig. 1). It should be noted that low fertilizer rates of fertilizer at the beginning of the season ensure good growth conditions for bacteria that dissolve mineral forms of phosphates. During the growing season the number of microorganisms in this group had significantly increased also in other variants with fertilizers. Application of Microhuminhad generally stimulated the development of microorganisms, that dissolve mineral forms of phosphates, at the most - in variants with green manure after effect.

The higher was the fertilizerrate the higher was the population of micromycetes in the rhizosphere of oats plants oats. Also the high number of micromycetes was observed in the variants with aftereffect of manure and organic-mineral fertilizer. The significant reduction in the number of microscopic fungi was observed during the study in the variants with Microhumin. This can be explained by the preoccupation of this ecological niche with the introduced microorganisms and their influence on the biochemical level on the development of micromycetes. The lowest number of microscopic fungi in the rhizosphere of oats plants was observed in the variants with aftereffect of green manure and use of biological preparation.

It was shown that upon the use of mineral fertilizers in doses that do not exceed $\mathrm{N}_{i} \mathrm{P}_{\mathrm{j}} \mathrm{K}_{\mathrm{f}}$ the reasonable formation of microorganisms associations in the rhizosphere soil of oats plants occurs.

The increase of fertilizers load results in unwanted changes in growth of soil microbiota and manifestation of their functional properties. Manure aftereffect was more favorable in terms of environmental impact approach. However, the simulation of biological denitrification was the disadvantage of organic fertilizer use. The emission of $\mathrm{N}: \mathrm{O}$ increases even furtherunder the use organic-mineral fertilizerthus indicating the need for quality manure conditioning before its application, for instance, by composting. The decrease of mineral nitrogenload is also appropriate in systems with the combination of organic and mineral fertilizers.

The most favorable in terms of its influence on the formation of microorganisms associations in the root zone of naked oats was plants cultivation on the backgroundof manure aftereffect and inoculation.

Oat yield had increasedin variants with aftereffect of $40 \mathrm{t} /$ ha manure and organic-mineral fertilizer (Table3). The positive impact on crop productivity was also observed in variants with green manureaftereffect, especially in combination with Microhumin. Higher rates of mineral fertilizers had led to higher yields, whereas their profitability was significantly reduced comparing with the application of the lower fertilizer doses. 
Table 3. The effect of seeds bacterization and fertilizers on the yield of naked oats plants

\begin{tabular}{|c|c|c|c|c|c|}
\hline \multirow{3}{*}{ Variants } & \multirow{3}{*}{$\begin{array}{lr}\text { Yield, } & \text { t/ha } \\
\text { (average } & \text { for } 5 \\
\text { years, } & 2011- \\
2015) & \end{array}$} & \multicolumn{4}{|c|}{ Increment } \\
\hline & & \multicolumn{2}{|c|}{ Fertilizers } & \multicolumn{2}{|c|}{ Bacterization } \\
\hline & & t/ha & $\%$ & t/ha & $\%$ \\
\hline \multicolumn{6}{|l|}{ Without inoculation } \\
\hline Without fertilizers (control) & 1.81 & - & - & - & - \\
\hline Aftereffect of manure $40 \mathrm{t} / \mathrm{ha}$ & 2.60 & 0.79 & 43.6 & - & - \\
\hline $\mathrm{N}_{\mathbb{N}} P \mathrm{~K}_{\mathbb{Z}}$ & 2.35 & 0.54 & 29.8 & - & - \\
\hline $\mathrm{N}_{\mathbb{N}} \mathrm{P}_{\mathrm{B}} \mathrm{K}_{6}$ & 2.90 & 1.09 & 60.2 & - & - \\
\hline $\mathrm{N}_{\|} \mathrm{P}_{\sharp} \mathrm{K}_{\tilde{3}}$ & 3.16 & 1.35 & 74.6 & - & - \\
\hline Aftereffect of manure $40 \mathrm{t} / \mathrm{ha}+\mathrm{N}_{\mathbb{A}} \mathrm{P}_{\mathrm{P}} \mathrm{K}_{\mathrm{K}}$ & 3.38 & 1.57 & 86.7 & - & - \\
\hline Aftereffect of green manure & 2.58 & 0.77 & 42.5 & - & - \\
\hline \multicolumn{6}{|l|}{ Inoculation with Microhumin } \\
\hline Without fertilizers (control) & 2.13 & - & - & 0.32 & 17.7 \\
\hline Aftereffect of manure $40 \mathrm{t} / \mathrm{ha}$ & 2.92 & $1.11^{*}$ & 61.3 & 0.32 & 12.3 \\
\hline $\mathrm{N}_{\mathrm{N}} \mathrm{P}_{\mathrm{S}} \mathrm{K}_{\mathbb{I}}$ & 2.68 & $0.87^{*}$ & 48.1 & 0.33 & 14.0 \\
\hline $\mathrm{N}_{\mathbb{A}} P_{\mathrm{N}} \mathrm{K}_{\mathrm{b}}$ & 3.23 & $1.42^{*}$ & 78.5 & 0.33 & 11.4 \\
\hline $\mathrm{N}_{\mathbb{N}} \mathrm{P}_{\mathfrak{B}} \mathrm{K}_{\mathfrak{i}}$ & 3.32 & $1.51^{*}$ & 83.4 & 0.16 & 5.1 \\
\hline Aftereffect of manure $40 \mathrm{t} / \mathrm{ha}+\mathrm{N}_{\mathrm{i}} \mathrm{P}_{\mathrm{i}} \mathrm{K}_{\mathrm{f}}$ & 3.65 & $1.84^{*}$ & 101.7 & 0.27 & 8.0 \\
\hline Aftereffect of green manure & 2.95 & $1.14^{*}$ & 63.0 & 0.37 & 14.3 \\
\hline LSD $_{\sharp} \quad$ experiment & 1.32 & & & & \\
\hline fertilizers & 0.15 & & & & \\
\hline inoculation and interaction & 0.78 & & & & \\
\hline
\end{tabular}

$\left.{ }^{*}\right)$ also due to the bacterization

The Microhuminefficiency was most evident in the variant without fertilizers, aftereffect of manure and green manure as well as on low fertilizer backgrounds. The effect of the biological preparation on crop performance was shown to be equivalent to the impact of fertilizers at $\mathrm{N}_{i} \mathrm{P}_{\mathrm{K}} \mathrm{K}$ dose. Thus, the crop yield upon the joint action of microbial preparation and $\mathrm{N}_{i} \mathrm{P}_{3} \mathrm{~K}_{j}$ dose of mineral fertilizer was $3.23 \mathrm{t} / \mathrm{ha}$ which was similar ( $3.16 \mathrm{t} / \mathrm{ha}$ ) to the yield observed in the variant with $\mathrm{N}_{\sharp} P_{\sharp} K_{\mathfrak{i}}$, but without seeds bacterization.

\section{Conclusions}

The aftereffect of manure and green manure and fertilizer norms that do not exceed $N_{i} P_{i} K_{i}$ was shown to be the most agronomically favorable for crop productivity and development of microorganisms upon the cultivation of naked oats plants on sod-podzolic soils. Seeds bacterization with microbial preparation Microhumin was proved to be efficient, as its effect on oats yield in experiment was equivalent to the action of

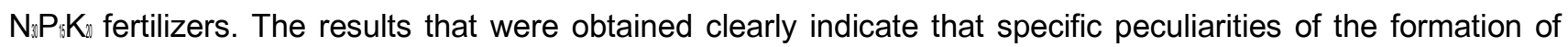
microorganisms associations and the expression of their functional activity area good indicatorsof the ecological state of soilagrocenoses. 


\section{References}

1. Gadzalo Ya.M. Agrobiology of plant rhizosphere/ Ya.M. Gadzalo, N.V. Patyka, A.S. Zaryshnyak. — Kyiv: Agrarnanauka, 2015. - $386 \mathrm{p}$.

2. Iutynskaya G.A. Bioregulation of plant-microbial systems / [G.A. lutynskaya, S.P. Ponomarenko, E.Y. Andreyuket al.] Eds. G.A. lutynskaya, S.P. Ponomarenko. - Kyiv: Nychlava, 2010. - 464 p.

3. Umarov M.M. Plant-microbe interactions and nitrogen transformation in biosphere // Molecular PlantMicrobe Interactions: New bridges Past and Future. 11-th Int. Congr. on Molecular Plant-Microbe Interactions, July 18-26, 2003. - St.-Petersburg, Russia, 2003. - P. 356.

4. Kurdysh I.K. Introduction of microorganisms in agroecosystems / I.K. Kurdysh. - Kyiv: Naukovadumka, 2010. - 197 p.

5. Microbial preparations in agriculture / [V.V. Volkogon, O.V. Nadkernychna, T.M. Kovalevskaet al.]; Ed. V.V. Volkogon. - Kyiv: Agrarnanauka, 2006. - 312 p.

6. Tikhonovich Y.A. Microbiological aspects of soil fertility and sustainable farming problems /

Y.A.Tikhonovich, Yu.V. Kruglov // Plodorodye. — 2006. ᄀ \#5(32). - P. 9-12.

7. Volkogon V.V. Experimental soil microbiology / [Volkogon V.V., Nadkernychna O.V., Tokmakova L.M. et al.]; Ed. V.V. Volkogon. — Kyiv: Agrarnanauka, 2010. - $464 \mathrm{p}$.

8. Umarov M.M. Acetylene method for nitrogen fixation determination in soil-microbiological studies / M.M. Umarov // Pochvovedenye. - 1976. ᄀ \#11. - P. 119-123.

9. Methods of soil microbiology and biochemistry / [Y.V. Aseeva, Y.P. Babeva, B.A. Byzovet al.]; Ed. D.G. Zvyagyncev. - Moscow: MGU, 1991. - 304 p.

10. Dospekhov B.A. Field experiment study methods with the basics of statistical data processing of results / B.A. Dospekhov. - Moscow: Agropromyzdat, 1985. - 351 p. 


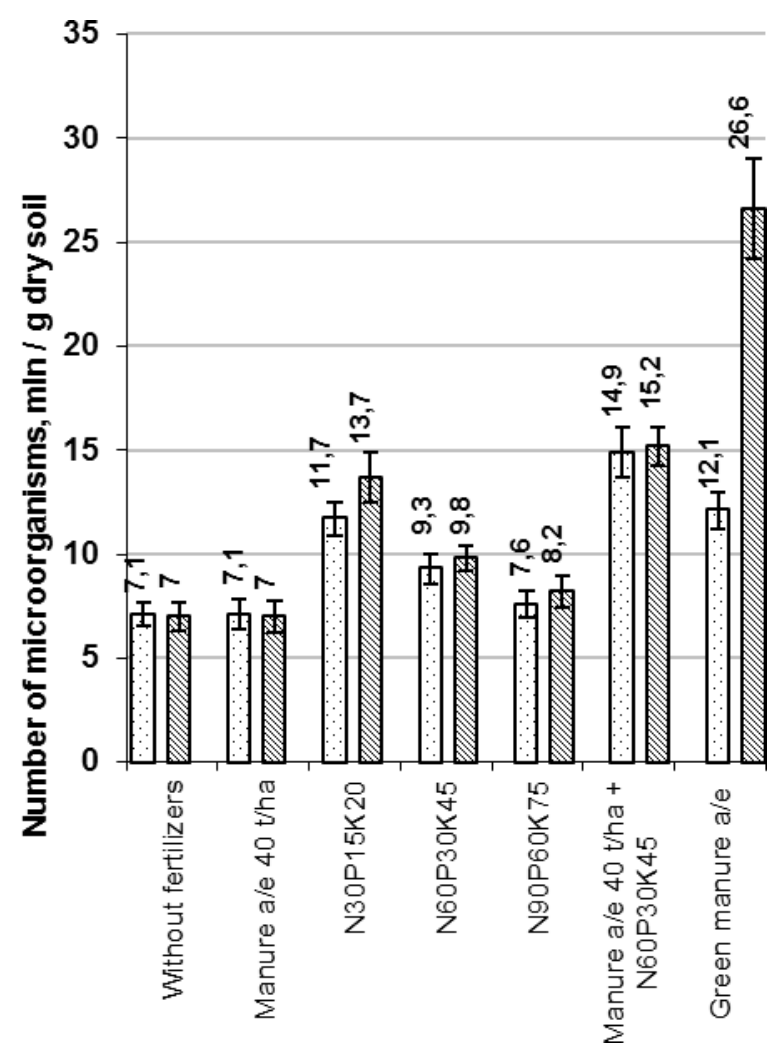

Tillering stage

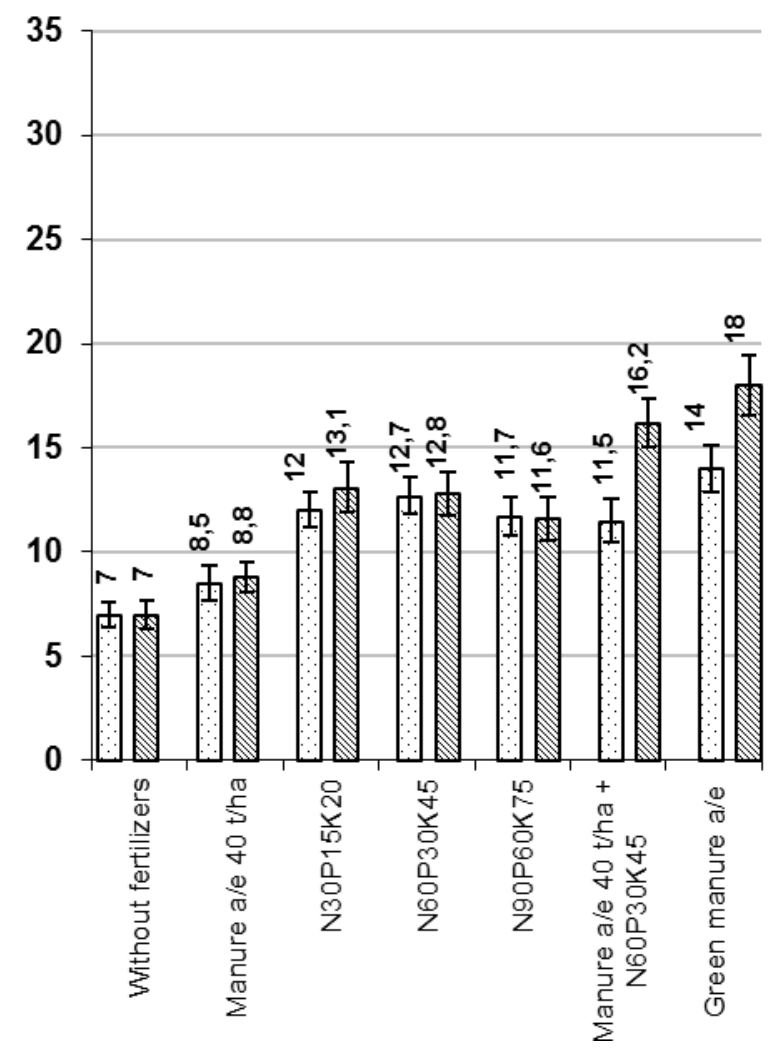

Stem elongation
口Without inoculation $\mathbf{Q}$ Microhumin

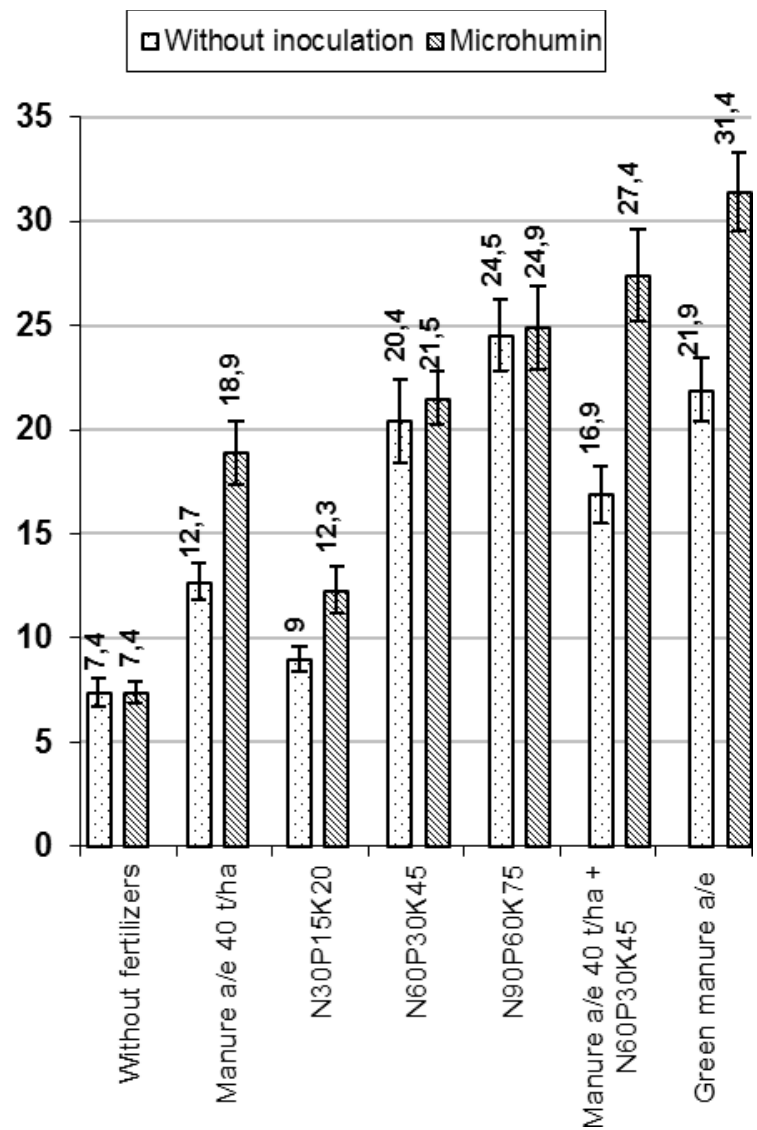

Milky-was ripeness

Fig. 1.The effect of seeds bacterization and fertilizers on the number of bacteria that dissolve mineral forms of phosphates in the rhizosphere soil of naked oatsplants 